and heterophil antibodies is obscure. The material is small, but one might speculate on the possibility that a past cytomegalovirus infection may protect against infections causing heterophil antibodies, and vice versa.

Serological tests have been the diagnostic method of the present study. Isolation of virus has not been attempted, but still the diagnosis is well documented. In all cases a significant rise in cytomegalovirus antibody titre was demonstrated in the complement-fixation test and in most cases also in the neutralization test. Proper controls were included in all tests. The Ad. 169 strain of cytomegalovirus was used in the complementfixation test and the neutralization test. The complementfixation test was the primary screening test, and when a sufficient amount of serum was obtained positive serum pairs were subsequently studied in the neutralization test with positive results. If there are antigenically different cytomegalovirus strains, either just one of these has been present here, or there are different strains with the same antigenic substance in common. Quantitative cross-neutralization tests with different cytomegalovirus strains have so far not been made.

There is hardly any doubt that the patients reported on have had an infection with cytomegalovirus or with an antigenically related agent. It is impossible to state, however, whether this is a primary acute infection or a disease of secondary reactivated type. The possibility of a complex microbiological cause of the disease with some kind of reactivation of a latent cytomegalovirus infection might thus possibly be discussed in some of the patients presented. In Cases 1 and 10 recurring urinary tract symptoms and in Case 11 repeated episodes of proctitis occurred before the definite onset of the actual disease. Cases 4 and 5 ran clinical courses suggestive of bacterial complications. However, in most of the patients the uniformity of the relation between clinical course and serological response seems to contradict the occurrence of a secondary reactivation of a latent cytomegalovirus infection.

\section{Summary}

Eleven cases of acquired cytomegalovirus infection occurring in different parts of Sweden and diagnosed by serological methods (complement-fixation test and neutralization test) are reported. A common clinical pattern was characterized by long-lasting fever, liver damage, relative lymphocytosis, raised E.S.R., and a significant rise in complement-fixing and neutralizing cytomegalovirus antibodies occurring more than two weeks after onset. A variety of other symptoms occurred, such as upper or lower respiratory tract infections, lymphadenopathy, anaemia, conjunctivitis, exanthema, gastroenteritis, vaginitis, and severe headache.

Serological cross-reactions between cytomegalovirus and many other infectious agents were looked for but not found. The implications of a possible negative correlation between heterophil antibodies and cytomegalovirus antibodies are discussed.

We wish to express our appreciation to Miss Irma Huttenlocher, Miss Gunilla Johannesson, and Mrs. Eva Olsson for competent technical assistance.

\section{REFERENCES}

Carlström, G. (1965). Acta paediat. (Uppsala), 54, 17.
Carlström, G. (1966). Svenska Läk.-Tidn, 63, 2135.

Carlström, G., Belfrage, S., and Swedberg, J. (1968). Scand. f. thorec.

Surg. In press.
Craighead, J. E., Hanshaw, J. B., and Carpenter, C. B. (1967). f. Amer. med. Ass., $201,725$.

Hanshaw, J. B., Betts, R. F., Simon, G., and Boynton, R. C. (1965). New Engl. F. Med., 272, 602.

Hanshaw, J. B., and Weller, T. H. (1961). f. Pediat., 58, 305.

Kääriäinen, L., Klemola, E., and Paloheimo, J. (1966). Brit. med. F., 1, 1270.

Klemola, E., and Kääriäinen, L. (1965). Brit. med. f., 2, 1099.

Rowe, W. P., Hartley, J. W., Cramblett, H. G., and Mastrota, F. M. (1958). Amer. F. Hyg., 67, 57.

Weller, T. H., and Hanshaw, J. B. (1962). New Engl. f. Med., 266, 1233.

Wong, T.-W., and Warner, N. E. (1962). Arch. Path., 74, 403.

\title{
Degenerative Changes in the Knee after Meniscectomy
}

\author{
J. P. JACKSON,* F.R.C.S.
}

Brit. med. F., 1968, 2, 525-527

Meniscectomy is one of the most frequently performed orthopaedic operations. The immediate results are mostly very satisfactory. Late degenerative changes have been reported, but very little information is available about their frequency or their causes.

Radiographic changes which occur after meniscectomy have been described by various authors. Vandendorp, Bastien, and Vandecasteele (1939) did little more than indicate that changes occurred. Fairbank (1948), however, who examined 107 cases three months to four years after operation, described ridging and flattening of the femoral condyle and narrowing of the joint space. He suggested that these changes might be a precursor of osteoarthritis. He found that they occurred in $37 \%$ of patients. His conclusion was "that meniscectomy is not wholly innocuous; it interferes at least temporarily with the mechanics of the joint. It seems likely that narrowing of the joint space will predispose to early degenerative changes, but a connexion between these appearances and later osteoarthritis is not yet established and is too indefinite to justify clinical deductions."

Saugmann-Jensen (1963) reported on 548 patients from the clinics in Copenhagen and found what he referred to as "Fairbank changes" in $23 \%$ after four and $38 \%$ after 10 to

* Harlow Wood Orthopaedic Hospital, Near Mansfield, Nottinghamshire.
15 years. He also thought that they were probably early osteoarthritic changes. He reported definite osteoarthritis as occurring in some six patients, though he did not define by what criteria the diagnosis was made.

To obtain a clearer picture of the incidence of degeneration after meniscectomy a series of patients were examined who were operated on at Harlow Wood Onthopaedic Hospital by a number of surgeons. The minimum postoperative period was five years. This allowed a reasonable time for the development of radiographic changes.

The term "degeneration" is used in this article rather than osteoarthritis, since in the first part it is a radiographic analysis. The changes referred to, however, are such that in the presence of pain a diagnosis of osteoarthritis would be acceptable.

The results reported have been submitted to statistical analysis and are considered valid.

\section{Material}

A total of 640 knees were reviewed. In 56 cases some of the radiographs were missing and seven were subsequently found to have a follow-up of less than five years. This left a total of 577 knees suitable for study. There were $516(89 \%)$ male and only $61(11 \%)$ female patients. Of these cases 480 
(79\%) had had medial meniscectomies performed and 129 (21\%) lateral. This is a ratio of $3.7: 1$, which is a higher proportion of medial meniscectomies than reported by Smillie (1962) $(1.8: 1)$ or Saugmann-Jensen (1963) $(1.5: 1)$.

The age at the time of meniscectomy is shown in Table I. This shows a peak in the fourth decade, which is perhaps rather older than might be expected but is similar to the group investigated by Saugmann-Jensen. Quite an appreciable number, $75(13 \%)$, however, were over 50 years of age at the time of operation.

TABLE I.-Age at Time of Operation
\begin{tabular}{|l|c|c|c|c|c|c|c}
\hline Age at operation _. & $<10$ & $10-19$ & $20-29$ & $30-39$ & $40-49$ & $50-59$ & $60+$ \\
Percentage of patients & 1 & 7 & 25 & 29 & 25 & 11 & 2 \\
\hline
\end{tabular}

The opposite knee was radiographed to act as a control. It was thought that this would eliminate any difference of sex, age, or occupation. Indeed, it seemed reasonable to assume that the opposite knee would have been subjected to much the same stresses and strains over the years as that in which the meniscus had been torn. Any inborn tendency to meniscus injury or anatomical variation would probably be the same for both knees. Those patients in whom there was some question of injury to this joint were excluded, and in some cases both knees had been treated by meniscectomy so that a control was not available. This left a total of 382 patients in whom the opposite knee was suitable for this purpose.

The radiographs were examined and the patients were divided into two groups:

(1) Those in whom there was no apparent radiographic change or in whom it was very slight. It was noticeable that in most joints after meniscectomy there was very slight lipping at the edge of the tibial condyle on the side of the operation. This was so common that in practically all cases diagnosis of the compartment from which a meniscus had been excised could be made from a study of the films. These changes could quite well have been caused by local damage at the time of operation, when the meniscus was detached by cutting the coronary ligament. In some of the cases the changes described by Fairbank-flattening and ridging of the femoral condyle-were apparent. Minor degrees of joint-narrowing were difficult to diagnose, since this often depended on the positioning of the patient and changes in rotation.

(2) The second group comprised those cases in which there were definite degenerative changes. There was well-marked lipping associated with some sclerosis. Cysts were rarely seen: this is in contradistinction to the hip, where they seem to be quite common. Many of the cases showed definite joint-narrowing on the side of the operation. The changes were such that when they were associated with pain osteoarthritis could reasonably be diagnosed (see Fig).

\section{Results}

Of the 577 cases $133(23 \%)$ showed definite degeneration and $444(77 \%)$ showed no change or only a minimal lipping. These changes were more frequent in the treated knees. Comparison with the control series showed that $21 \%$ of the meniscectomy group were affected and only $5 \%$ of the controls (Table II).

TABLE II.-Comparison of Knee After Meniscectomy and the Opposite Knee Where This Was Used as a Control

\begin{tabular}{lll|c|c}
\hline & & & Postmeniscectomy & Control \\
\hline $\begin{array}{l}\text { Normal } \\
\text { Degenerative change }\end{array}$ &.. &.. & $300(79 \%)$ & $\begin{array}{c}364(95 \%) \\
18(5 \%)\end{array}$ \\
\hline
\end{tabular}

Though the degenerative changes increased with the length of follow-up in the knees in which operation was carried out, this was to some extent also apparent in the controls. It is likely that the increase was in part due to the normal ageing process. However, it will be seen (Table III) that it was much greater after meniscectomy. The percentage of knees showing degeneration was significantly higher in all groups of the treated joints.

TABLE III.-Percentage of Degenerative Changes After Meniscectomy TABLE III.-Percentage of Degenerative Changes
Compared with Control Series

\begin{tabular}{|c|c|c|c|c|c|}
\hline $\begin{array}{l}\text { Years of follow-up } \\
\text { Meniscectomy } \\
\text { Control }\end{array}$ & $\ddot{0}$ & $\begin{array}{r}<10 \\
21 \% \\
4 \%\end{array}$ & $\begin{array}{c}10-19 \\
23 \% \\
4 \%\end{array}$ & $\begin{array}{l}20-29 \\
53 \% \\
13 \%\end{array}$ & $\begin{array}{c}30-40 \\
67 \% \\
0\end{array}$ \\
\hline
\end{tabular}

There may, of course, be a number of different reasons for degeneration after meniscectomy, but there seems to be two principal causes. These are (1) damage inflicted by the torn meniscus, and (2) loss of the meniscus.

Damage to the articular cartilage is not infrequently seen at operation. These changes vary from slight softening of the anticular cartilage to areas of ulceration. Helfet (1959) described them in some detail and showed that they occur in quite welldefined areas, related either to the tear of the meniscus or to the anterior cruciate ligament which causes trauma of the femoral condyle if rotational movements of the knee are blocked. I have examined 100 unselected cases at operation and found these changes in $29 \%$. The possibility that they may lead to degeneration in the knee can only be estimated indirectly.

Since the diagnosis cannot be made with certainty before operation it is impossible to compare groups in half of whom the meniscus has been excised and in the other half it still remains. If, however, it is considered that degeneration is a

Left: Appearance of right knee before medial meniscectomy in 1937. Lateral meniscectomy carried out in 1939. Centre and right: Appearances at follow-up in 1964. Right knee shows definite degenerative changes on both sides of the joint. Left knee included as a control. 
result of the trauma inflicted by the torn meniscus before its removal, then clearly the longer the period before operation the greater the likelihood of degenerative changes. The patients were thenefore divided into two groups-those whose preoperative history was less than six months from the initial injury and those with a longer history. Comparison of the percentages showing degeneration in these two groups revealed no difference (Table IV). Differing periods of preoperative history were also compared, but the numbers showing degeneration remained remarkably constant (Table V). It is statistically highly probable, therefore, that the length of preoperative history does not determine the onset of degenerative changes and that the damage inflicted by the torn meniscus is of no significance in the later production of arthrosis.

TABLE IV.-Comparison of Knees After Meniscectomy of Those With Under Six Month' and Those With Over Six Months' Pre-operative History

\begin{tabular}{lll|c|c} 
& & $\begin{array}{c}\text { Under 6 Months } \\
(210)\end{array}$ & $\begin{array}{c}\text { Over 6 Months } \\
(367)\end{array}$ \\
\hline $\begin{array}{l}\text { Normal } \\
\text { Degenerative change }\end{array}$ & $\because$ &. & $\begin{array}{c}163(78 \%) \\
47(22 \%)\end{array}$ & $\begin{array}{c}281(77 \%) \\
86(23 \%)\end{array}$ \\
\hline
\end{tabular}

TABLE V.-Comparison of Percentage of Degenerative Changes Found

\begin{tabular}{|c|c|c|c|}
\hline \multicolumn{2}{|c|}{$\begin{array}{l}\text { Length of } \\
\text { Preoperative History }\end{array}$} & $\begin{array}{l}\text { No. of } \\
\text { Cases }\end{array}$ & $\begin{array}{l}\text { Degenerative } \\
\text { Change }\end{array}$ \\
\hline $\begin{array}{l}\text { Less than } 6 \text { months } \\
6-12 \text { months } \\
1-2 \text { years } \\
2-5 \text { years } \\
5-30 \text { years }\end{array}$ & 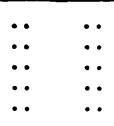 & $\begin{array}{r}210 \\
115 \\
88 \\
110 \\
54\end{array}$ & $\begin{array}{l}47(22 \%) \\
26(23 \%) \\
21(24 \%) \\
23(21 \%) \\
16(29 \%)\end{array}$ \\
\hline
\end{tabular}

\section{Discussion}

This investigation showed that a high proportion of knees underwent degenerative change after the meniscus had been removed. It is difficult to establish the cause beyond doubt. It seems most likely, however, that this change is a direct result of the loss of the meniscus. The exact function of that structure is still a matter of some conjecture. MacConaill (1932) stated that it acts by reducing friction when joint movements are carried out rapidly, and he estimates that it does this by as much as $20 \%$. Fairbank (1948) thought that it had a function in weight-bearing and that its presence afforded some protection to the joint surfaces. Whatever its precise role it does seem likely that it is at least in part protective, and its loss will therefore lead to increased wear and tear of the articular cartilage. Though many knees will regenerate some form of meniscus it is unlikely that this can as efficiently protect the joint (Bruce and Walmsley, 1937 ; Smillie, 1944).

Once degenerative changes have occurred, further injury, often of a minor nature, may precipitate osteoarthritis, which is a painful condition. There is no doubt, therefore, that many of these patients will in the course of time suffer from this disease. Indeed, many of the patients reviewed were already suffering from osteoarthritis, though some had pain for which there was no obvious cause.

Correlation of the degenerative changes with pain was not always easy to interpret. It was quite obvious on clinical and radiographic grounds that many of these patients did indeed suffer in this way. Not all of those who showed radiographic changes, however, had pain. The percentage complaining of pain is shown in Table VI.
TABle VI.-Percentage of Patients Complaining of Pain of Significant Intensity After Meniscectomy. Not All These Patients Showed Radiographic Evidence of Degeneration

\begin{tabular}{l|l|l|l|l}
\hline $\begin{array}{l}\text { Years of follow-up } \\
\text { Percentage of patients } . .\end{array}$ & $<10$ & $10-19$ & $20-29$ & $\begin{array}{c}30-40 \\
27\end{array}$ \\
\hline
\end{tabular}

If loss of the meniscus can lead to degenerative changes in a high proportion of patients then this is a factor which should be taken into account before the meniscus is removed. Current teaching on this subject is that if it is considered that the meniscus is torn it should be removed, not only to relieve the patient's symptoms but also to prevent further damage to the articular cantilage and the possibility of subsequent osteoarthritis. The conclusions from this investigation suggest that a more conservative attitude should be adopted. A patient who is suffering from very troublesome symptoms will certainly require meniscectomy. Every effort, however, should be made to confirm the diagnosis, if necessary prolonging the period of observation until this becomes clearer. Once arthrotomy has been decided on and the joint opened, careful examination of the other structures should be carried out before the meniscus is removed. Indeed, if no definite tear is observed inspection of the other meniscus through a second incision is worth while, since in many cases there may be doubt about which one is torn.

There are many cases of internal derangement of the knee which are eventually explored and from which a normal meniscus is removed. Certainly in some of these cases operation could be avoided if this policy of prolonged observation were rigidly adopted. Patients might well demand this if they were made aware of the long-term results.

Finally, these results are of medico-legal significance. A young man in his early twenties at the time of operation could envisage the real possibility of developing osteoarthritis from the age of 50 onwards. If he were in some manual occupation he might well be forced to change his employment at a time of life when this could be most difficult.

\section{Summary}

Examination of knees after meniscectomy shows that a high proportion undergo degenerative change when some years have elapsed. These changes are more frequent than can be accounted for by the normal ageing process. Though damage to a meniscus can lead to trauma of the articular cartilage it seems unlikely that it is the cause. The most likely cause is loss of the meniscus.

I wish to thank all the surgeons at Harlow Wood Orthopaedic Hospital who have allowed me to use cases under their care for this review. I should also like to thank Miss H. M. Briggs, Research Secretary at Harlow Wood Orthopaedic Hospital, for her invaluable help in the preparation of this paper.

\section{REFERENCES}

Bruce, J., and Walmsley, R. (1937). Brit. f. Surg., 25, 17.

Fairbank, T. J. (1948). f. Bone ft Surg., 30B, 664.

Helfet, A. J. (1959). F. Bone ft Surg., 41B, 319.

MacConaill, M. A. (1932). F. Anat., 66, 210.

Saugmann-Jensen, J. (1963). Knaeets Minisklaesioner, Meniscus-Injurias of the Knee Joint. Kobenhavn.

Smillie, I. S. (1944). Brit. F. Surg., 31, 398.

Smillie, I. S. (1962). Injuries of the Knee foint, 3rd ed. Edinburgh.

Vandendorp, Bastien, and Vandecasteele (1939). Rev. Orthop., 26, 629. 